\title{
A Study on Biosorption Potential of Aspergillus sp. of Tannery Effluent
}

\author{
Arasappan Sugasini*, Kalyanaraman Rajagopal, Narasimhan Banu \\ Department of Biotechnology, Vels University, Chennai, India \\ Email: suga81@gmail.com
}

Received 25 July 2014; revised 26 August 2014; accepted 25 September 2014

Copyright (C) 2014 by authors and Scientific Research Publishing Inc.

This work is licensed under the Creative Commons Attribution International License (CC BY). http://creativecommons.org/licenses/by/4.0/

c) (†) Open Access

\section{Abstract}

Chromium toxicity is one of the major environmental pollutants. As conventional methods for heavy metal removal are very expensive, bioremediation using fungi is extensively explored. Therefore in the present investigation, out of 23 fungi isolated from tannery effluent, 4 Aspergillus species namely $A$. terreus, $A$. tamarii, $A$. flavus and $A$. niger were selected for evaluating chromium tolerance and biosorption potential. Growth of the fungi was tested using various concentrations of Potassium dichromate (Cr VI) viz., $1 \mathrm{mM}, 3 \mathrm{mM}$ and $5 \mathrm{mM}$ amended in potato dextrose agar. For all the fungi, growth was observed only in $1 \mathrm{mM}$ and $3 \mathrm{mM}$. No growth was observed in $5 \mathrm{mM}$. Biosorption efficiency of both live and alkali pretreated Aspergillus species was compared. In the present study, alkali pretreated form exhibited highest biosorption efficiency than the live biomass in which $A$. terreus showed highest chromium biosorption potential compared to the other fungi.

\section{Keywords}

Aspergillus, Chromium, Alkali Pretreated, Biosorption, Live Biomass

\section{Introduction}

Heavy metal pollution has become a worldwide environmental issue over the last few decades. Chromium is one of the major pollutants present in waste waters from various industrial units such as electroplating, fertilizers, pigments, tanning, mining etc. [1]. Chromium exists in two stable oxidation states, i.e., trivalent Cr (III) and hexavalent $\mathrm{Cr}(\mathrm{VI})$ [2]. The latter is highly water soluble and reported to be a potent carcinogen [3]. Prolonged exposure to hexavalent chromium (Cr(VI)) causes serious health hazards such as cancer in the digestive tract and lungs, epigastric pain, nausea, vomiting, severe diarrhoea and hemorrhage [4]. Therefore, Cr(VI) removal is

*Corresponding author. 
very essential before it is being discharged into the aqueous streams [5].

Various conventional methods are available for heavy metal removal which is very expensive and not ecofriendly [6]. Biosorption using biomaterials has received considerable attention for detoxification of toxic heavy metals from wastewaters [4] as they possess various merits such as low cost, high efficiency, minimization of chemical and or toxic sludge, regeneration of biosorbent, metal recovery etc. [7]. Fungi are known to tolerate and detoxify metals by several mechanisms and are considered as potential biosorbent for heavy metal removal [8].

Both living (bioaccumulation) and non-living (biosorption) microbial biomass can act as effective metal scavengers [9]. Dead fungal biomass has been used in a number of studies because it is not affected by adverse operating conditions and can solve the environment problems of high toxicity [10]. Fungal phenolic polymers and melanins possess many potential metal-binding sites with oxygen-containing groups including carboxyl, hydroxyl, carbonyl and methoxyl groups being particularly important in biosorption [11].

Modifications of the cell wall of microorganisms have been explored extensively to increase the sorption efficiency of metal ions by microbial biomass using several modifying agents. The treatment varies with the type of biomass and the metal ions to be biosorbed [12]. Different physical methods were used for pretreatment such as boiling, heating, autoclaving and freeze drying or chemical treatments such as, with acids, detergents, alkalis and organic/inorganic chemicals, or a combination of both physical and chemical methods [13]-[17]. These types of pretreatments modify the cell surface which is essential for biosorption either by removing or masking the groups or exposing more metal binding sites [12].

Alkaline (caustic) treatment could enhance metal binding by biomass. The alkaline treatments, including sodium hydroxide, potassium hydroxide, alkaline detergents or other alkaline reagents ruptures the cell wall of the microbes and exposes additional functional groups for metal ion binding [18].

The aim of this study was to investigate the chromium tolerance of 4 Aspergillus spp. and to study the effect of sodium hydroxide pretreatment of Aspergillus spp. on chromium biosorption.

\section{Materials and Methods}

\subsection{Collection of Tannery Effluent}

The tannery effluent was collected from the common treatment effluent plant located in Chrompet, Chennai, India.

\subsection{Isolation and Identification of Fungi}

Potato Dextrose Agar (PDA) was used for culturing fungi from tannery effluent. $100 \mu \mathrm{l}$ of the effluent was spread on the PDA plate. The inoculated plates were incubated at $27^{\circ} \mathrm{C}$ for 5 days. The fungi were identified using Lactophenol cotton blue [19].

\subsection{Screening of Aspergillus Species for Chromium Tolerance}

The chromium tolerance of $A$. terreus, A. tamarii, A. flavus and A. niger was evaluated at various concentrations $(1,3 \& 5 \mathrm{mM})$ of Potassium dichromate $\left(\mathrm{K}_{2} \mathrm{Cr}_{2} \mathrm{O}_{7}\right)$ supplemented in PDA and was poured in the petriplates. 6 $\mathrm{mm}$ disc of each fungus was inoculated and incubated at $27^{\circ} \mathrm{C}$ for 5 days. The culture in PDA without $\mathrm{K}_{2} \mathrm{Cr}_{2} \mathrm{O}_{7}$ served as control. Reduction of radial growth rate was used as an index for metal tolerance. To compare the heavy metal tolerance of each species, a parallel Index of Tolerance (T.I) was calculated as a percentage value from the ratio:

$$
\text { T.I }=\frac{\text { Radial growth rate in metal treatment }}{\text { Radial growth rate in control }}
$$

The isolates exhibiting better growth after incubation were considered as chromium tolerant [20]. The tolerance studies were conducted in duplicates and the mean values were used to compare the tolerance of Aspergillus spp.

\subsection{Preparation of Biosorbent}

\subsubsection{Live Biomass}

$6 \mathrm{~mm}$ disc of each fungal culture was transferred to Potato Dextrose (PD) broth and incubated at $27^{\circ} \mathrm{C}$ for 5 days. 
Then it was harvested and washed with distilled water and stored at $-20^{\circ} \mathrm{C}$.

\subsubsection{Alkali Pretreated Biomass}

Live harvested biomass (50 gm) was treated with $0.5 \mathrm{~N}$ Sodium hydroxide (NaOH) for 30 min followed by washing with distilled water until the $\mathrm{pH}$ of the solution reached 7. The pretreated biomass was autoclaved at 15 $\mathrm{lb} / \mathrm{inch}^{2}$ for $20 \mathrm{~min}$. and was dried at $60^{\circ} \mathrm{C}$ for $24 \mathrm{hr}$ in hot air oven and powdered using mortar and pestle [21].

\subsection{Biosorption Experiment}

$0.1 \mathrm{gm}$ of live and alkali pretreated A. terreus, A. tamarii, A. niger, and A. flavus was inoculated into $100 \mathrm{ml}$ metal solution containing 1 , $3 \& 5 \mathrm{mM}$ of $\mathrm{K}_{2} \mathrm{Cr}_{2} 0_{7}$. The flasks were kept on rotary shaker $125 \mathrm{rpm}$ for $18 \mathrm{hr}$ at $30^{\circ} \mathrm{C}$. Then the solution was centrifuged at $10,000 \mathrm{rpm}$ for $15 \mathrm{~min}$. The content of the supernatant was analysed after proper digestion and dilution by atomic absorption spectrophotometer (Perkin elmer 5300 DV). Metal solution without biomass addition served as control.

Bioadsorption experiments were carried out in duplicate and average values were used in the analysis. Bioadsorption capacity, i.e. amount of metal ions (mg) bioadsorbed per gm (dry mass) of biomass was calculated using the following equation:

$$
\mathrm{Q}=\left(\mathrm{C}_{\mathrm{i}}-\mathrm{C}_{\mathrm{f}} / \mathrm{m}\right) \mathrm{V}
$$

where $\mathrm{Q}=\mathrm{mg}$ of metal ion bioadsorbed per gm of biomass, $\mathrm{C}_{\mathrm{i}}=$ initial metal ion concentration mg/l, $\mathrm{C}_{\mathrm{f}}=$ final metal ion concentration $\mathrm{mg} / \mathrm{l}, \mathrm{m}=$ mass of biomass in the reaction mixture gm, $\mathrm{V}=$ volume of the reaction mixture (1) [21].

\section{Results and Discussion}

In the present study, 23 fungi were isolated from tannery effluent (Table 1). This includes 9 Aspergillus sp., 5 Penicillium sp., Paecilomyces variotii, Trichoderma viride, Graphium sp., Scopulariopsis brevicaulis, Sporothrix schenckii, Fusarium oxysporum and Acremonium strictum. Shazia et al. [22] have isolated 19 fungi from heavy metal contaminated soils. Similar to our present study, Aspergillus sp. were frequently (12 out of 19) encountered than other fungi. Aspergillus sp. were observed to be the most commonly occurring in the heavy metal contaminated soils as also reported by Ahmad et al. [21] and Zafar et al. [23].

Several Aspergillus species have been used for heavy metal ion adsorption such as A. niger [24], A. fumigatus [25], A. niveus [26], A. versicolor [27], A. flavus [28], A. terreus [29] and A. cristatus [30] etc. Sen and Ghosh Dastidar [31] have also studied Aspergillus sp. from industrial wastewater for hexavalent chromium removal. Shazia et al., [22] also reported that Aspergillus isolates were the most resistant to all the metals tested, namely cadmium, copper and nickel.

Hence, in the present investigation, four Aspergillus species viz., Aspergillus terreus, Aspergillus niger, Aspergillus flavus and Aspergillus tamarii were taken under study.

Microbes in metal polluted environments adapt to toxic concentrations of heavy metals and become metal resistant [32]. Therefore in the present study, Chromium tolerance of the Aspergillus species was checked using 1, 3 and $5 \mathrm{mM}$ of Potassium dichromate solution where chromium exist as $\mathrm{Cr}(\mathrm{VI})$. Growth was observed in $1 \mathrm{mM}$ and $3 \mathrm{mM}$. No growth was observed in $5 \mathrm{mM}$. The results were presented in Plate 1. Growth inhibition could have resulted due to chromium toxicity at higher concentration.

Metal tolerance index was calculated for all the 4 Aspergillus sp. (Table 2). For $1 \mathrm{mM}$ Potassium dichromate concentration, the chromium tolerance index of $A$. terreus and A. niger was same, i.e., 0.5, whereas for A. flavus and $A$. tamarii, it was 0.3 and 0.2 respectively and for $3 \mathrm{mM}$ Potassium dichromate concentration, chromium tolerance index for A. terreus, A. niger decreased to 0.3 and for A. flavus, the tolerance index remained same. For A. tamarii also there was a decrease, i.e., it was observed to be 0.01 . The variation in degree of tolerance was most probably due to the potential variation in the mechanism of tolerance [33].

In this study two types of biosorbent of the Aspergillus species were used for Cr(VI) removal. One is the live biomass and the other, is the Alkali pretreated biomass. Then it was used in Cr(VI) biosorption similar to that of Yan and Viraraghavan [18]. Biosorption potential of both alkali pretreated and live biomass of A. terreus, A. tamarii, A. niger and A. flavus was analyzed using metal solution containing $\mathrm{K}_{2} \mathrm{Cr}_{2} \mathrm{O}_{7}(\mathrm{Cr}(\mathrm{VI})$ ) at various concentrations of 1, 3 and $5 \mathrm{mM}$ at pH 7 suggested by Ahmad et al. [21]. 
Table 1. List of fungi isolated from tannery effluent.

\begin{tabular}{cc}
\hline S. No. & Name of Fungi \\
\hline 1 & Aspergillus terreus \\
2 & Aspergillus tamarii \\
3 & Aspergillus niger \\
4 & Aspergillus flavus \\
5 & Aspergillus nidulans \\
6 & Aspergillus fumigatus \\
7 & Aspergillus versicolor \\
8 & Aspergillus japonicus \\
9 & Aspergillus flavipes \\
10 & Penicillium solitum \\
11 & Penicillium sp. 2 \\
12 & Penicillium oxalicum \\
13 & Penicillium frequentans \\
14 & Penicillium sp. 3 \\
15 & Paecilomyces variotii \\
16 & Trichoderma viride \\
17 & Graphium sp. \\
18 & Scopulariopsis brevicaulis \\
19 & Sporothrix schenckii \\
20 & Fusarium oxysporum \\
21 & Acremonium strictum \\
22 & Cladosporium cladosporoides \\
23 & \\
\hline
\end{tabular}

Table 2. Metal tolerance index of Aspergillus species towards hexavalent chromium.

\begin{tabular}{cccc}
\hline \multirow{2}{*}{ Name of the fungus } & \multicolumn{3}{c}{ Metal tolerance index (TI) for Cr concentration } \\
\cline { 2 - 4 } & $\mathbf{1 ~} \mathbf{~ m M}$ & $\mathbf{3 ~} \mathbf{~ m}$ & $\mathbf{5} \mathbf{~ m M}$ \\
\hline Aspergillus terreus & 0.5 & 0.3 & - \\
Aspergillus tamarii & 0.2 & 0.01 & - \\
Aspergillus niger & 0.5 & 0.3 & - \\
Aspergillus flavus & 0.3 & 0.3 & - \\
\hline
\end{tabular}

-: No growth.

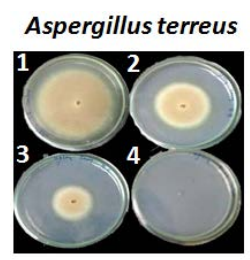

Aspergillus niger

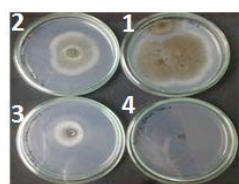

Aspergillus tamarii

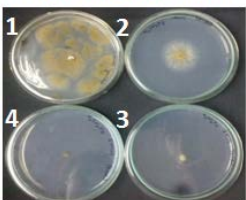

Aspergillus flavus

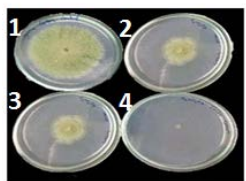

Plate 1. Screening of chromium tolerance of Aspergillus species: (1) control; (2) $1 \mathrm{mM}$ potassium dichromate; (3) $3 \mathrm{mM}$ potassium dichromate; (4) $5 \mathrm{mM}$ potassium dichromate. 
The amount of $\mathrm{Cr}(\mathrm{VI})$ removed by live and alkali pretreated A. terreus, A. tamarii, A. flavus and A. niger was given in Figures 1-4 respectively. The results depicted that in all case, $\operatorname{Cr}(\mathrm{VI})$ biosorption increased with increase in metal ion concentration.

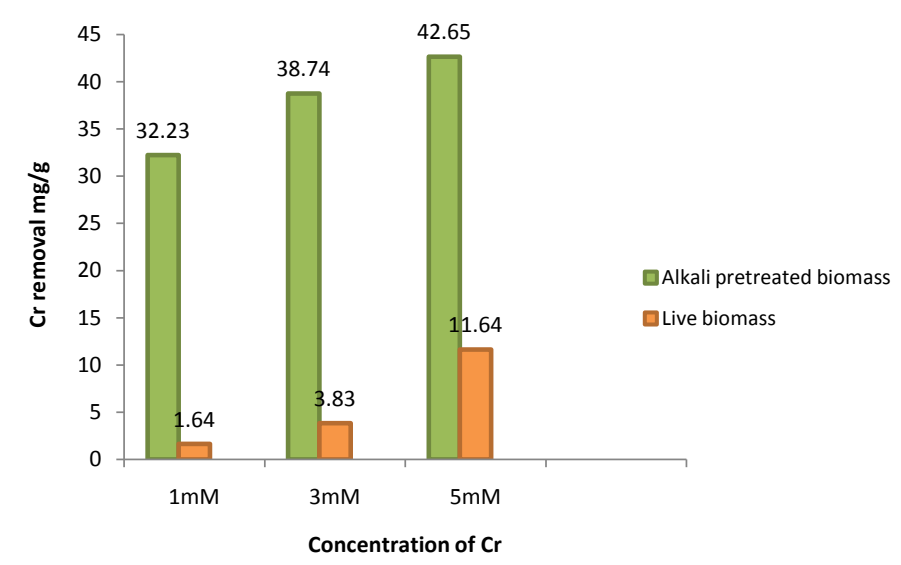

Figure 1. Comparison of chromium biosorption potential of alkali pretreated and live $A$. terreus.

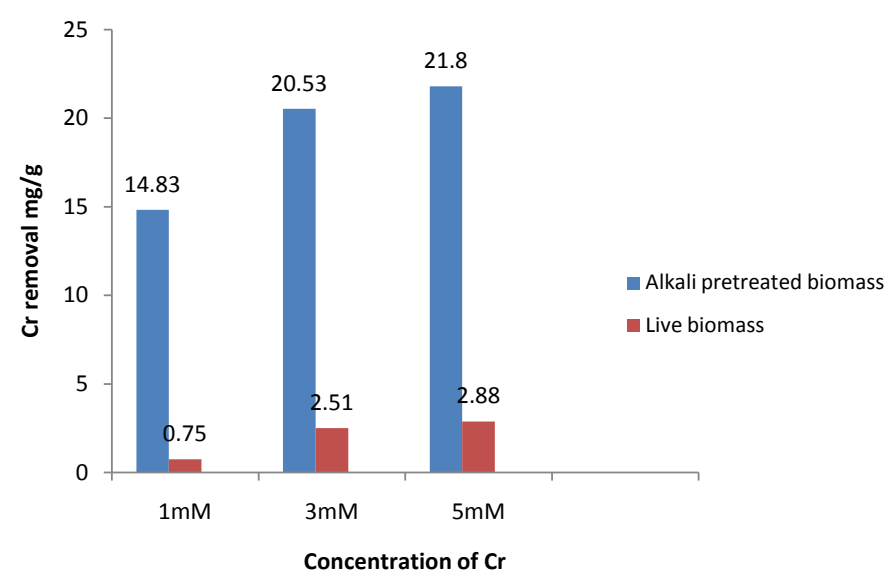

Figure 2. Comparison of chromium biosorption potential of alkali pretreated and live A. tamari.

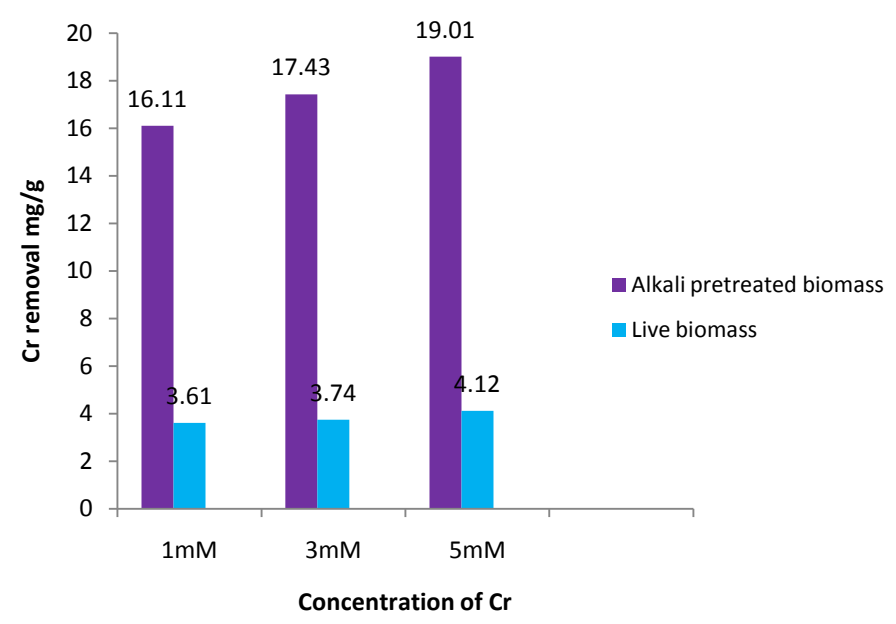

Figure 3. Comparison of chromium biosorption potential of alkali pretreated and live A. flavus. 


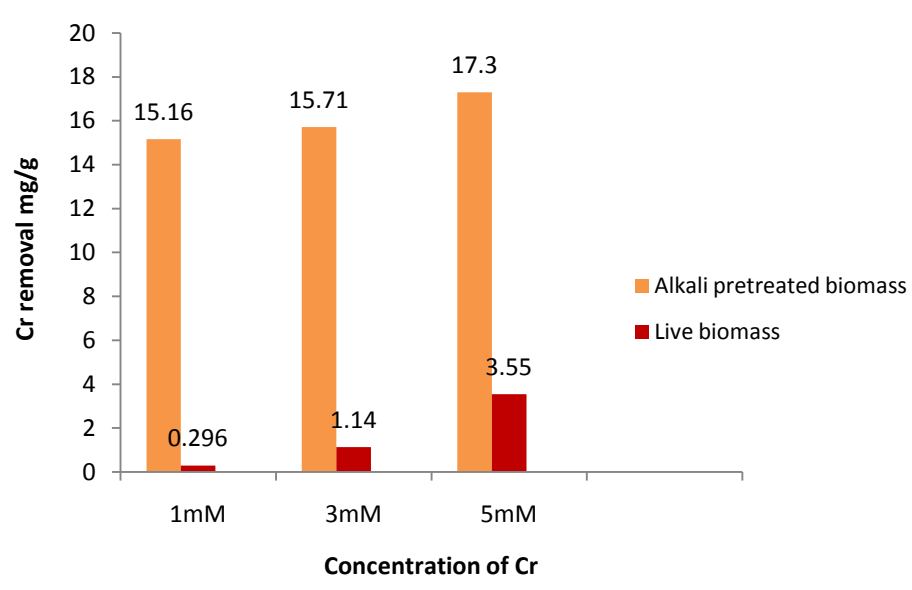

Figure 4. Comparison of chromium biosorption potential of alkali pretreated and live A. niger.

At $1 \mathrm{mM}$ concentration of Potassium dichromate $\left(\mathrm{K}_{2} \mathrm{Cr}_{2} \mathrm{O}_{7}\right)$, live A. flavus exhibited maximum $\mathrm{Cr}(\mathrm{VI})$ removal, i.e., $3.61 \mathrm{mg} / \mathrm{g}$ and A. niger showed minimum $\mathrm{Cr}(\mathrm{VI})$ removal, i.e., $0.296 \mathrm{mg} / \mathrm{g}$. In alkali pretreated form, maximum $\mathrm{Cr}(\mathrm{VI})$ removal was exhibited by $A$. terreus $(32.23 \mathrm{mg} / \mathrm{g})$ whereas $A$. tamarii showed lowest biosorption (14.83 mg/g). At $3 \mathrm{mM}$ concentration of $\mathrm{K}_{2} \mathrm{Cr}_{2} \mathrm{O}_{7}$, A. terreus showed maximum $\mathrm{Cr}(\mathrm{VI})$ removal, $3.83 \mathrm{mg} / \mathrm{g}$ and $38.74 \mathrm{mg} / \mathrm{g}$, whereas A. niger showed minimum $\mathrm{Cr}(\mathrm{VI})$ removal, i.e., $1.14 \mathrm{mg} / \mathrm{g}$ and $15.71 \mathrm{mg} / \mathrm{g}$ in live and alkali pretreated form respectively. At $5 \mathrm{mM}$ concentration of $\mathrm{K}_{2} \mathrm{Cr}_{2} \mathrm{O}_{7}$, the amount of $\mathrm{Cr}(\mathrm{VI})$ removed by $A$. terreus was higher, i.e., $11.64 \mathrm{mg} / \mathrm{g}$ and $42.65 \mathrm{mg} / \mathrm{g}$ in live and alkali pretreated form, respectively whereas live $A$. tamarii exhibited lowest biosorption value, i.e., $2.88 \mathrm{mg} / \mathrm{g}$ and in alkali pretreated form, A. niger showed minimum $\mathrm{Cr}(\mathrm{VI})$ removal, i.e., $17.3 \mathrm{mg} / \mathrm{g}$.

In this study, out of 4 Aspergillus species selected for chromium biosorption, A. terreus exhibited highest biosorption efficiency, in which alkali pretreated form showed maximum biosorption efficiency at higher concentrations of Potassium dichromate.

Raja Rao and Bhargavi [34] also used sodium hydroxide for pretreating A. niger and studied lead and nickel biosorption using atomic absorption spectrophotometer. The maximum removal of lead was observed around $75 \%$ - 80\% at pH 6 - 7 with maximum adsorbent dose of $0.2 \mathrm{~g} / \mathrm{ml}$. Nickel was observed to have maximum biosorption of around $50 \%-60 \%$ at $\mathrm{pH} 5-8$.

Das et al. [35] investigated the effect of sodium hydroxide pretreatment on $\mathrm{Cd}^{2+}$ biosorption capacity of Pleurotus florida. Pretreatment of biomass with $\mathrm{NaOH}$ showed maximum increase on biosorption of $\mathrm{Cd}^{2+}$ by approximately three times in comparison with living biomass (from 3.21 to $9.76 \mathrm{mg} / \mathrm{g}$ ). The reason may be due to the removal of surface impurities, rupture of cell membrane and exposure of available binding sites for metal bioadsorption after pretreatment.

Abdoun-Ouallouche et al. [36] investigated the effect of different pretreatment processes on biosorption capacity of Rhizopus stolonifer biomass to remove lead and mercury. The highest metal uptake values $(12.10 \mathrm{mg} / \mathrm{g}$ and $9.75 \mathrm{mg} / \mathrm{g}$ for $\mathrm{Pb}$ and $\mathrm{Hg}$ respectively) were obtained by $\mathrm{NaOH}$ treated biomass. Chikkhara and Dhankar [37] also used base treated $A$. niger for $\mathrm{Cr}(\mathrm{VI})$ removal and observed $65.28 \mathrm{mg}$ of metal uptake.

In the case of alkali pre-treatment, bioadsorption capacity of Mucor rouxii biomass was significantly enhanced in comparison with autoclaving. Similar enhancement in metal uptake capacity of the fungal biomass regarding alkali pretreatment was recorded by El-Sayed [38] and Das et al. [35].

In the present study, even though the metal tolerance index of A. terreus and A. niger is more or less similar, A. terreus showed excellent chromium biosorption efficiency compared to the latter. Similar findings were recorded by Zafar et al. [23]. Aspergillus sp. 1 which was less tolerant than Aspergillus sp. 2 accumulated $\mathrm{Cr}$ and $\mathrm{Cu}$ at a higher level suggesting that there was little if any correlation between metal tolerance and biosorption properties of the test fungi.

\section{Conclusion}

The present study concludes that fungi isolated from tannery effluent have the ability to resist higher concentra- 
tions of chromium. This may be due to the development of tolerance or adaptation of the fungi to heavy metals. Among the four Aspergillus species, A. terreus exhibited excellent chromium adsorption capacity. Sodium hydroxide pretreatment improved the biosorption efficiency than that of untreated fungi. After further investigations, sodium hydroxide pretreated $A$. terreus could be effectively utilized to remove hexavalent chromium from industrial effluents.

\section{Acknowledgements}

The authors sincerely thank Dr. Ishari K. Ganesh, Chancellor, Vels University for providing infrastructure facilities to carry out this research work. We also thank IIT-SAIF for their help in heavy metal analysis by atomic absorbance spectrophotometer.

\section{References}

[1] Volesky, B. (2001) Detoxification of Metal-Bearing Effluents: Biosorption for the Next Century. Hydrometallurgy, 59, 203-216. http://dx.doi.org/10.1016/S0304-386X(00)00160-2

[2] Sivaprakash, A., Aravindhan, R., Raghava Rao, J. and Unni Nair, B. (2009) Kinetics and Equilibrium Studies on the Biosorption of Hexavalent Chromium from Aqueous Solutions. Applied Ecology and Environmental Research, 7, 4557.

[3] Congeevaram, S., Dhanarani, S., Park, J., Dexilin, M. and Thamaraiselvi, K. (2007) Biosorption of Chromium and Nickel by Heavy Metal Resistant Fungal and Bacterial Isolates. Journal of Hazardous Materials, 146, 270-277. http://dx.doi.org/10.1016/j.jhazmat.2006.12.017

[4] Abdel-Razek, A.S. (2011) Removal of Chromium Ions from Liquid Waste Solutions Using Immobilized Cunninghamella elegans. Nature and Science, 9, 211-219.

[5] Sen, M. and Ghosh Dastidar, M. (2010) Chromium Removal Using Various Biosorbents. Iranian Journal of Environmental Health Science Engineering, 7, 182-190.

[6] Vijayaraghavan, K. and Yun, Y.S. (2008) Bacterial Biosorbents and Biosorption. Biotechnology Advances, 26, 266291. http://dx.doi.org/10.1016/j.biotechadv.2008.02.002

[7] Ahalya, N., Ramachandra, T.V. and Kanamadi, R.D. (2003) Biosorption of Heavy Metals. Research Journal of Chemistry and Environment, 7, 71-78.

[8] Magyarosy, A., Laidlaw, R.D., Kilaas, R., Echer, C., Clark, D.S. and Keasling, J.D. (2002) Nickel Accumulation and Nickel Oxalate Precipitation by Aspergillus niger. Applied Microbiology and Biotechnology, 59, 382-388. http://dx.doi.org/10.1007/s00253-002-1020-X

[9] Rahim, M.K., Mostafa, C., Hossein, M., Yusef, K.K. and Shahin, O. (2012) Biosorption of Cd and Ni by Inactivated Bacteria Isolated from Agricultural Soil Treated with Sewage Sludge. Ecohydrology and Hydrobiology, 12, 191-198. http://dx.doi.org/10.1016/S1642-3593(12)70203-3

[10] Chu, K. and Hasim, M. (2004) Quantitative Analysis of Copper Biosorption by the Microalga Chlorella vulgaris. Environmental Engineering Science, 21, 139-147. http://dx.doi.org/10.1089/109287504773087318

[11] Gadd, G.M. (2009) Biosorption: Critical Review of Scientific Rationale, Environmental Importance and Significance for Pollution Treatment. Journal of Chemical Technology and Biotechnology, 84, 13-28. http://dx.doi.org/10.1002/jctb.1999

[12] Gupta, R., Ahuja, P., Khan, S., Saxena, R.K. and Mohapatra, H. (2000) Microbial Biosorbents: Meeting Challenges of Heavy Metal Pollution in Aqueous Solutions. Current Science, 78, 967-973.

[13] Bai, R.S. and Abraham, T.E. (2002) Studies on Enhancement of Cr(VI) Biosorption by Chemically Modified Biomass of Rhizopus nigricans. Water Research, 36, 1224-1236. http://dx.doi.org/10.1016/S0043-1354(01)00330-X

[14] Awofolu, O.R., Okonkwo, J.O., Merwe, R.R.D., Badenhorst, J. and Jordaan, E. (2006) A New Approach to Chemical Modification Protocols of Aspergillus niger and Sorption of Lead Ion by Fungal Species. Electronic Journal of Biotechnology, 9, 340-348.

[15] Loukidou, M.X., Matis, K.A., Zouboulis, A.L. and Kyriakidou, M.L. (2003) Removal of As(V) from Wastewaters by Chemically Modified Fungal Biomass. Water Research, 37, 4544-4552. http://dx.doi.org/10.1016/S0043-1354(03)00415-9

[16] Park, D., Yun, Y. and Park, J.M. (2005) Studies on Hexavalent Chromium Biosorption by Chemically-Treated Biomass of Ecklonia sp. Chemosphere, 60, 1356-1364. http://dx.doi.org/10.1016/j.chemosphere.2005.02.020

[17] Kavita, B., Limbachia, J. and Keharia, H. (2011) Hexavalent Chromium Sorption by Biomass of Chromium Tolerant Pythium sp. Journal of Basic Microbiology, 51, 173-182. http://dx.doi.org/10.1002/jobm.201000191 
[18] Yan, G. and Viraraghavan, T. (2000) Effect of Pretreatment on the Bioadsorption of Heavy Metals on Mucor rouxi. Water South Africa Journal, 26, 119-123.

[19] Barnett, H.L. and Hunter, B.B. (1999) Illustrated Genera of Imperfect Fungi. Prentice Hall Inc., Upper Saddle River.

[20] Tahir, A. (2012) Resistant Fungal Biodiversity of Electroplating Effluent and Their Metal Tolerance Index. In: Sebayang, D., Ed., Electroplating, InTech, Lahore, 137-144.

[21] Ahmad, I., Zafar, S. and Aqil, F. (2005) Heavy Metal Biosorption Potential of Aspergillus and Rhizopus sp. Isolated from Wastewater Treated Soil. Journal of Applied Sciences \& Environmental Management, 9, 123-126.

[22] Shazia, A., Mahmood-ul-Hassan, M., Rizwan, A., Vishandas, S. and Muhammad, Y. (2013) Metal Tolerance Potential of Filamentous Fungi Isolated from Soils Irrigated with Untreated Municipal Effluent. Soil \& Environment, 32, 55-62.

[23] Zafar, S., Aqil, F. and Ahmad, I. (2007) Metal Tolerance and Biosorption Potential of Filamentous Fungi Isolated from Metal Contaminated Agricultural Soil. Bioresource Technology, 98, 2557-2561. http://dx.doi.org/10.1016/j.biortech.2006.09.051

[24] Srivastava, S. and Thakur, I.S. (2006) Biosorption Potency of Aspergillus niger for Removal of Cr(VI). Current Microbiology, 53, 232-237. http://dx.doi.org/10.1007/s00284-006-0103-9

[25] Al-Garni, S.M., Ghanem, K.M. and Bahobail, A.S. (2009) Biosorption Characteristics of Aspergillus fumigatus in Removal of Cadmium from an Aqueous Solution. African Journal of Biotechnology, 8, 4163-4172.

[26] Karaca, H., Tay, T. and Kivanç, M. (2010) Kinetics of Lead Ion Biosorption from Aqueous Solution onto Lyophilized Aspergillus niveus. Water Practice and Technology, 5, 1-10.

[27] Cabuk, A., Ilhan, S., Filik, C. and Çaliskan, F. (2005) $\mathrm{Pb}^{2+}$ Biosorption by Pretreated Fungal Biomass. Turkish Journal of Biology, 29, 23-28.

[28] Akar, T. and Tunali, S. (2006) Biosorption Characteristics of Aspergillus flavus Biomass for Removal of Pb(II) and $\mathrm{Cu}(\mathrm{II})$ Ions from an Aqueous Solution. Bioresource Technology, 97, 1780-1787. http://dx.doi.org/10.1016/j.biortech.2005.09.009

[29] Sun, Y.M., Horng, C.Y., Chang, F.L., Cheng, L.C. and Tian, W.X. (2010) Biosorption of Lead, Mercury and Cadmium Ions by Aspergillus terreus Immobilized in a Natural Matrix. Polish Journal of Microbiology, 59, 37-44.

[30] Hassan, S.W. and El-Kassas, H.Y. (2012) Biosorption of Cadmium from Aqueous Solutions Using a Local Fungus Aspergillus cristatus (Glaucus Group). African Journal of Biotechnology, 11, 2276-2286.

[31] Sen, M. and Ghosh Dastidar, M. (2007) Biosorption of Cr(VI) By Resting Cells of Aspergillus sp. Iranian Journal of Environmental Health Science and Engineering, 4, 9-12.

[32] Prasenjit, B. and Sumathi, S. (2005) Uptake of Chromium by Aspergillus foetidus. Journal of Material Cycles and Waste Management, 7, 88-92. http://dx.doi.org/10.1007/s10163-005-0131-8

[33] Roane, T.M. (2000) Lead Resistance to Two Bacterial Isolates from Heavy Metals-Contaminated Soils. Microbial Ecology, 37, 218-224. http://dx.doi.org/10.1007/s002489900145

[34] Raja Rao, P. and Bhargavi, Ch. (2013) Biosorption of Heavy Metals Using Pretreated Biomass of Fungal Species. International Journal of Chemistry and Chemical Engineering, 3, 171-180.

[35] Das, N., Charumathi, D. and Vimala, R. (2007) Effect of Pretreatment on $\mathrm{Cd}^{2+}$ Biosorption by Mycelial Biomass of Pleurotus florida. African Journal of Biotechnology, 6, 2555-2558.

[36] Abdoun-Ouallouche, K., Djefal-kerrar, A., Amrani, S. and Zerrouki, S. (2014) Removal of Lead and Mercury from Aqueous Solutions by Pretreated Rhizopus stolonifer. International Proceedings of Chemical, Biological \& Environmental Engineering, 65, 1.

[37] Chikkhara, S. and Dhankhar, R. (2008) Biosorption of Cr(VI) Ions from Electroplating Effluent Using Immobilized Aspergillus niger Biomass. Journal of Environmental Biology, 29, 773-778.

[38] El-Morsy, E.S.M. (2004) Cunninghamella echinulata, a New Biosorbent of Metal Ions from Polluted Water in Egypt. Mycologia, 96, 1183-1189. http://dx.doi.org/10.2307/3762133 
Scientific Research Publishing (SCIRP) is one of the largest Open Access journal publishers. It is currently publishing more than 200 open access, online, peer-reviewed journals covering a wide range of academic disciplines. SCIRP serves the worldwide academic communities and contributes to the progress and application of science with its publication.

Other selected journals from SCIRP are listed as below. Submit your manuscript to us via either submit@scirp.org or Online Submission Portal.
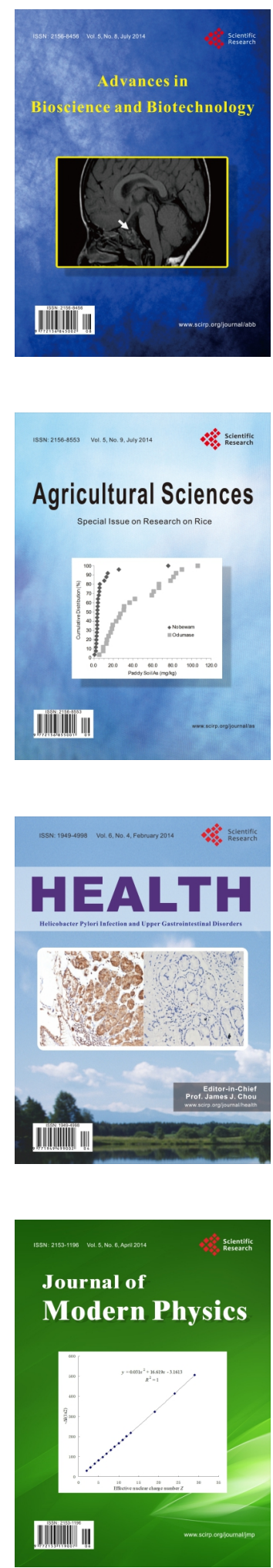
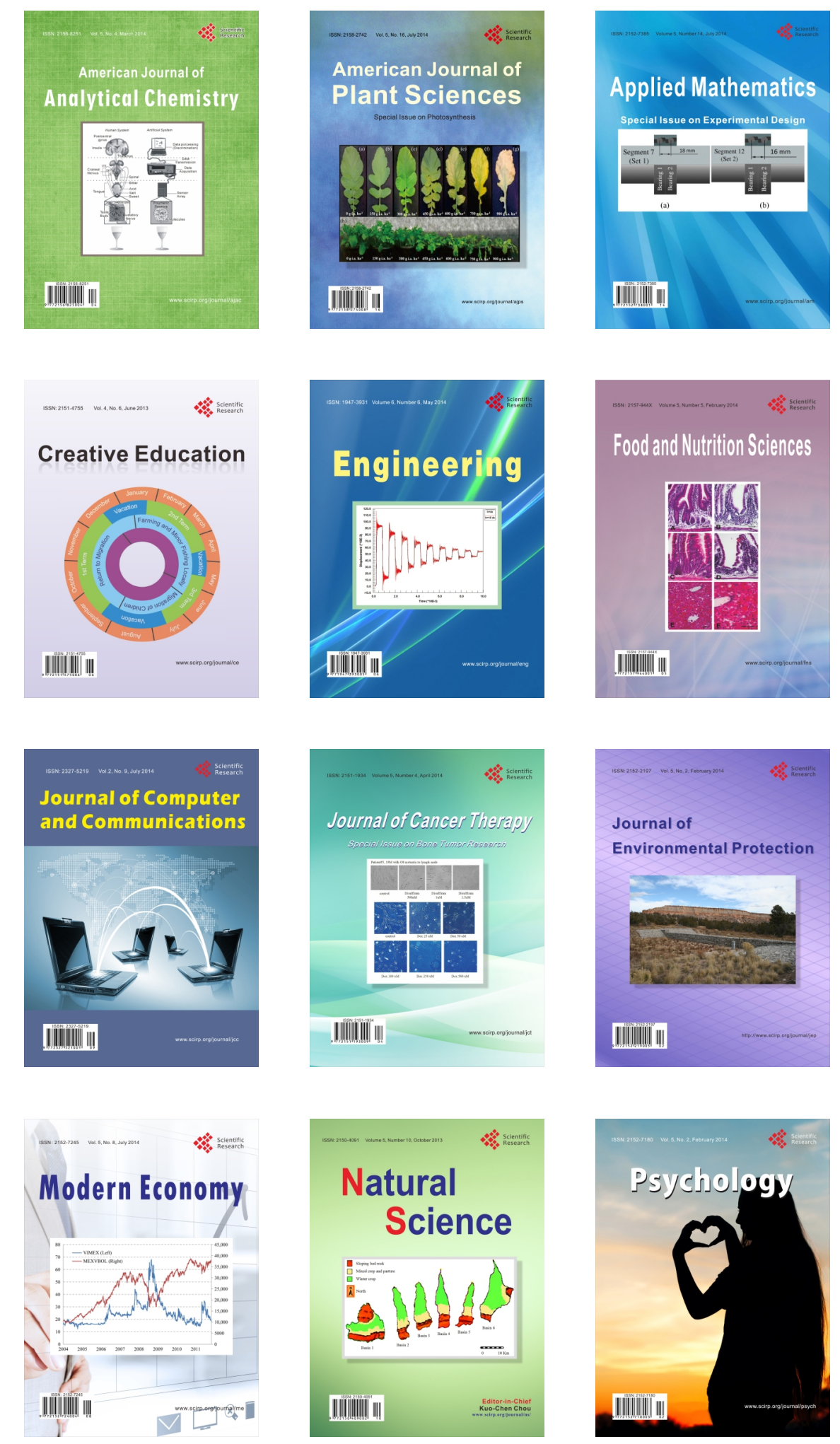